\title{
Social Security Household Benefits: Measuring Program Knowledge
}

\author{
Katherine G. Carman and Angela A. Hung
}




\title{
Social Security Household Benefits: Measuring Program Knowledge
}

\author{
Katherine G. Carman \\ RAND
}

Angela A. Hung

RAND

September 2018

\author{
Michigan Retirement Research Center \\ University of Michigan \\ P.O. Box 1248 \\ Ann Arbor, MI 48104 \\ www.mrrc.isr.umich.edu
}

(734) 615-0422

\section{Acknowledgements}

The research reported herein was performed pursuant to a grant from the U.S. Social Security Administration (SSA) funded as part of the Retirement Research Consortium through the University of Michigan Retirement Research Center Award RRC08098401-10. The opinions and conclusions expressed are solely those of the author(s) and do not represent the opinions or policy of SSA or any agency of the federal government. Neither the United States government nor any agency thereof, nor any of their employees, makes any warranty, express or implied, or assumes any legal liability or responsibility for the accuracy, completeness, or usefulness of the contents of this report. Reference herein to any specific commercial product, process or service by trade name, trademark, manufacturer, or otherwise does not necessarily constitute or imply endorsement, recommendation or favoring by the United States government or any agency thereof.

\section{Regents of the University of Michigan}

Michael J. Behm, Grand Blanc; Mark J. Bernstein, Ann Arbor; Shauna Ryder Diggs, Grosse Pointe; Denise Ilitch, Bingham Farms; Andrea Fischer Newman, Ann Arbor; Andrew C. Richner, Grosse Pointe Park; Ron Weiser, Ann Arbor; Katherine E. White, Ann Arbor; Mark S. Schlissel, ex officio 


\title{
Social Security Household Benefits: Measuring Program Knowledge
}

\begin{abstract}
Social Security offers two types of benefits for spouses: spousal and survivor benefits. Regardless of his or her own work history, a married individual can claim spousal Social Security benefits, which are equal to half of his or her spouse's Social Security benefits. Furthermore, a widow or widower can claim survivor benefits and receive or his or her deceased spouse's full benefit if it is larger than his or her own benefit. Ideally, married individuals think about the impact of their Social Security choices on their spouse. However, if people do not fully understand the rules for the spousal and survivor benefits, they may make suboptimal choices, not only about Social Security claiming, but perhaps also about labor and marriage decisions. In this paper we make use of new data from the Understanding America Study to assess households' understanding of these benefits. Overall, our results suggest that knowledge of spousal and survivors benefits is low. Furthermore, our results suggest that people's perceptions of their knowledge is misaligned with their actual knowledge, with many perceiving that they know more about Social Security than they actually do. The results in this paper suggest particular areas where policymakers might be able to increase knowledge of spousal and survivors benefits. However, future research is needed to better understand how to increase knowledge in this area.
\end{abstract}

\section{Citation}

Carman, Katherine G., and Angela A. Hung. 2018. "Social Security Household Benefits: Measuring Program Knowledge," University of Michigan Retirement Research Center (MRRC) Working Paper, WP 2018-384. Ann Arbor, MI.

http://mrdrc.isr.umich.edu/publications/papers/pdf/wp384.pdf

\section{Authors' acknowledgements}

We thank Dave Knapp and Phil Armour for their helpful comments, and Melissa Bradley for her assistance with our focus groups. 


\section{Introduction}

Social Security spousal benefits offer households the opportunity to claim benefits for one spouse who either doesn't qualify for Social Security benefits based on his or her own earnings history or who qualifies for benefits equal to less than one half of the other spouse's benefit. Furthermore, survivors benefits allow widows or widowers to claim their spouse's full benefit. The availability of household benefits from Social Security has important implications for determining the optimal timing of claiming, necessary savings for retirement, and potentially has implications for marriage decisions. Under a neoclassical household model, spouses will optimize their claiming decisions taking into account not only the impact on their own benefits but also the impact on their spouse's benefits. The availability of spousal benefits might also have implications for the labor force participation decisions on the intensive or extensive margins. Couples who are not aware of these benefits may make suboptimal decisions. Recent survey evidence from the University of Southern California's Understanding America Study (UAS) suggests that spouses may not have strong understanding of spousal benefits. Only 28 percent of respondents report that they are very or somewhat knowledgeable about how their own Social Security claiming decisions affects their spouses' benefits. Almost 18 percent of respondents believe that someone who has never worked is not entitled to Social Security benefits even if his/her spouse is entitled to Social Security benefits.

In this research, we use newly collected focus group data and UAS survey data to assess the state of knowledge about spousal and survivors benefits. Our survey asks more detailed questions about knowledge of Social Security spousal benefits and survivors benefits than have previously been asked. In focus group discussions, we found that many participants were unaware of spousal benefits and that when shown Social Security's description of benefits, they 
had many questions and misunderstandings. As a result, we designed a new survey to gauge the level of knowledge in the general population. Our survey includes knowledge questions on how working, marital status, and length of marriage effect eligibility for spousal and survivors benefits, as well as the amount of benefits and the timing of claiming. We also assessed confidence in one's knowledge by eliciting respondents' subjective probability distribution over their correct responses to the knowledge questions. Overall, we find that while many are aware of spousal and survivors benefits, knowledge about eligibility and benefit amounts is relatively low. Furthermore, respondents are overconfident about how many questions they answer correctly. We find that individuals who have higher financial literacy, primary earners, and those with greater self-assessed knowledge of Social Security in general have greater objective knowledge of spousal and survivors benefits. Looking at couples where both spouses responded to our survey, we do not find evidence of specialization, defined as one spouse having significantly more knowledge than the other.

\section{Background and research questions}

Retirement planning is typically a joint household decision-making process, and therefore, in studying retirement planning, the household often is the more appropriate unit of analysis. Research on retirement timing has found that many couples retire at the same time or close to the same time (Hurd 1990; Maestas 2001; Coile 2004; Gustman and Steinmeier 2004; Banks, Blundell, and Rivas 2010; Michaud and Vermeulen 2011). Furthermore, changes in labor income or retirement income for one spouse can affect the labor supply and retirement decisions of the other spouse (Baker 2002; Lalive and Staubli 2014). Given the complementarities, neoclassical models of households would predict that couples jointly plan for retirement. Social Security benefits represent a significant portion of household income in retirement: Social Security 
provided more than 50 percent of income for 39.5 percent of individuals between the ages of 65 and 69 in 2012 (Social Security Administration, 2014). Claiming decisions should be made to consider the impact on both members of a couple. However, our previous research (Carman and Hung 2017) finds that private household retirement savings in 401k and IRAs tend to be concentrated among one spouse, and that patterns of saving may be consistent with individual rather than joint decisions. This suggests that households may not approach retirement planning as a joint decision, and similarly they may not approach Social Security claiming as a joint decision. One reason for this may be a failure to fully understand the Social Security spousal and survivors benefits.

Social Security offers two important sources of retirement income for spouses. The first is the spousal benefit, which allows a spouse to receive Social Security retirement benefits off his or her own earnings record, or a spousal benefit, whichever is higher. For example, suppose the wife $^{1}$ is the secondary earner in a married couple. The wife's spousal benefit, at her full retirement age, is equal to 50 percent of the husband's benefit at his full retirement age. Second, widows may claim a survivor benefit, equal to the full amount of the deceased's benefit, if it is greater than the widow's own benefit. However, the amount of the survivor benefit that a wife can receive is affected by the husband's age at the time of claiming. ${ }^{2}$

In particular, the key research questions are:

- Do individuals know that they are entitled to Social Security spousal benefits?

- Do individuals know how spousal and survivors benefits are determined?

- Do individuals know whether and how the timing of Social Security benefit claiming impacts their spousal and survivors benefits?

\footnotetext{
${ }^{1}$ In these explanations, we use "wife" for simplicity; the rules also apply to the husband or for same-sex, married couples, and some same-sex couples in nonmarital legal relationships

${ }^{2}$ Divorced spouses who were married for at least 10 years may also qualify for spousal and survival benefits. However, because joint household decision-making is not expected among divorced couples, we exclude this from our research.
} 


\section{Survey module on spousal and survivors benefits}

To answer our key research questions, we developed a new survey module to field on the UAS. We began by conducting focus groups to better understand current knowledge and to help develop the survey instrument. Focus groups can be appropriate as a formative approach when a new topic is being explored, and when discussion may help elucidate divergent viewpoints.

\section{Focus groups}

We conducted two focus groups consisting of 13 to 14 participants each; there were 27 participants in total. The focus groups took place in Baltimore, Maryland, in May 2018. The groups were restricted to individuals who are married, involved in household financial decisionmaking, and eligible for Social Security benefits but not yet receiving benefits. Participants were selected to be balanced in terms of gender, age, and education. The groups were stratified based on whether the participant was the household's primary or secondary earner.

To recruit our participants, we employed an independent market research firm that maintains a database of approximately 50,000 individuals who reside in the Baltimore metropolitan area. The market research firm used a standardized script developed by the authors to invite participants by telephone to participate in a focus group.

In each discussion, we began with asking participants about retirement planning in general. The discussion turned to Social Security in particular, with discussion of how well participants understand how Social Security benefits work in general, followed by discussion of how knowledgeable they were about their own expected Social Security retirement benefits and their spouses' expected Social Security retirement benefits. We then asked participants about their knowledge of spousal retirement benefits. We handed out an information sheet adapted from the 
Social Security website ${ }^{3}$ on spousal retirement benefits and discussed whether the provided information clarified confusion on spousal benefits. Finally, we discussed Social Security survivors benefits.

From the focus group discussions, there were several qualitative insights on how participants think about Social Security retirement benefits, spousal benefits, and survivors benefits that helped guide development of the survey instrument.

First, we found that awareness of Social Security spousal benefits was low in both groups, but compared to the primary earner group, the secondary earner group was more familiar with spousal benefits. However, it is important to note that more participants in the secondary earner group expressed that they were somewhat knowledgeable about Social Security in general and that they regularly check their own Social Security benefits than in the primary earner group. Given low overall awareness of spousal benefits, we developed the survey instrument to separately measure awareness of spousal benefits and knowledge about spousal benefit program rules.

Second, both focus groups were more familiar with survivors benefits than spousal benefits. Familiarity with survivors benefits mainly stemmed from personal experience with survivors benefits, either from receiving survivors benefits as a child or from a parent's experience with survivors benefits after the other parent died. Even though awareness of the survivors benefits program was higher than awareness of the spousal benefits program, very few participants expressed knowledge on program rules on eligibility or how benefits are calculated. Given the difference in awareness of the survivors benefits program as compared to the spousal benefits program, we designed the survey to separately measure awareness and knowledge of

\footnotetext{
${ }^{3}$ https://www.ssa.gov/planners/retire/applying7.html
} 
survivors benefits and awareness and knowledge of spousal benefits.

Lastly, both groups expressed pessimism about whether Social Security will provide retirement benefits at retirement age, and cited this as a reason for not expending effort to learn about their expected Social Security benefits, spousal benefits, or survivors benefits. Therefore, we include in the survey an item that measures confidence that Social Security will provide retirement benefits for the respondent, and the analysis will account for differences in confidence about the Social Security retirement program.

\section{Survey module}

The survey module begins with ascertaining whether the respondent is the household's primary or secondary earner. Respondents are then asked about their overall confidence in the Social Security retirement program, followed by questions on the respondent's awareness of Social Security spousal benefits. The survey module then includes five knowledge questions on Social Security rules on spousal benefits (correct answers are bolded and asterisked):

Please answer the next set of five questions on spousal retirement benefits to the best of your ability. If you are unsure, please just give us your best guess. For these questions, we'll use primary beneficiary to describe an individual who will receive retirement benefits based on his/her own earnings.

1. Among current spouses and partners, which statement best describes who is eligible for Social Security spousal retirement benefits? Social Security spousal retirement benefits are available to:
a. The current spouse of the primary beneficiary, for couples who have been married for at least one year.*
b. The current spouse of the primary beneficiary, for couples who have been married for at least 10 years.
c. The current spouse or partner of the primary beneficiary, for couples who have lived together for at least one year.
d. The current spouse or partner of the primary beneficiary, for couples who have lived together for at least ten years.
e. None of the above
f. Don't know 
2. Among divorced spouses, which statement best describes who may be eligible for Social Security spousal retirement benefits? Social Security spousal retirement benefits may be available to:
a. The former spouse of the primary beneficiary, for couples who were married for at least one year.
b. The former spouse of the primary beneficiary, for couples who were married for at least 10 years.*
c. The former spouse of the primary beneficiary is never eligible.
d. None of the above
e. Don't know

3. If a primary beneficiary's spouse claims Social Security spousal benefits, then does the primary beneficiary's own Social Security retirement benefits increase, decrease, or stay the same?
a. Increase
b. Decrease
c. Stay the same*
d. Don't know

4. Current spouses can claim spousal retirement benefits before the primary beneficiary claims his/her own benefits
a. True
b. False*
c. Don't know

5. The maximum Social Security retirement benefit that a spouse can receive is equivalent to:
a. The spouse's retirement benefit PLUS one-half the primary beneficiary's retirement benefit at Full Retirement Age
b. The spouse's retirement benefit OR one-half the primary beneficiary's retirement benefit at Full Retirement Age, whichever is higher*
c. Don't know

Immediately after these five questions, we measure self-assessed knowledge by eliciting respondents' subjective probability distributions over the number of correct responses they think they provided, following Moore and Healy (2008) and Anderson, Baker, and Robinson (2017). In particular, we ask respondents:

For the previous five questions on spousal benefits, you could have answered between zero and five correctly. We would like to know how many you think you got correct. Please tell us the percent chance that you got: 


\begin{tabular}{|l|l|}
\hline All five correct & $\ldots \%$ \\
\hline Exactly four correct & $\ldots \%$ \\
\hline Exactly three correct & $\ldots \%$ \\
\hline Exactly two correct & $\ldots \%$ \\
\hline Exactly one correct & $\ldots \%$ \\
\hline No correct answers & $\ldots \%$ \\
\hline
\end{tabular}

Comparing the actual number of knowledge questions that a respondent answered correctly to the reported subjective expected number of correct questions allows us to measure whether respondents think they know more than they actually know (what Moore and Healy 2008 call overestimation), whether they think they know less than they actually know, or if their perception of how much they know is well calibrated. A respondent's complete subjective probability distribution over the number of correct responses allows us to measure the certainty that he assigns to his expectation on number of correct responses.

We then ask a question about the respondent's awareness of Social Security survivors benefits followed by five knowledge questions on Social Security rules on survivors benefits (correct answers are bolded and asterisked):

Please answer the next set of five questions on survivors benefits to the best of your ability. If you are unsure, please just give us your best guess.

1. If the deceased had been married for at least nine months prior to death, then his/her widow/widower may be eligible for survivors benefits.
a. True*
b. False
c. Don't know

2. If the deceased's widow/widower ever remarries, then the widow/widower is no longer eligible for survivors benefits.
a. True
b. False*
c. Don't know

3. If the deceased had been living with a partner for at least 10 years, then the surviving partner may be eligible for survivors benefits
a. True
b. False ${ }^{*}$ 


\section{Don't know}

4. If the deceased had ever been divorced, then the deceased's surviving former spouse may be eligible for survivors benefits, if they were married for at least 10 years before they divorced.
a. True*
b. False
c. Don't know

5. If the deceased did not have any dependents at the time of death, the maximum Social Security retirement benefit that a widow/widower can receive is equivalent to:
a. The widow's/widower's retirement benefit PLUS a benefit based on what the deceased would have been eligible to receive had he/she survived
b. The widow's/widower's retirement benefit OR a benefit based on what the deceased would have been eligible to receive had he/she survived*

C. Don't know

Finally, as with the knowledge questions on spousal benefits, we measure self-assessed knowledge of survivors benefits by eliciting respondents' subjective probability distributions over the number of correct responses they think they provided on survivors benefits.

\section{Data}

The UAS is an online representative panel of approximately 6,000 American Households. For this survey we selected a sample of 2,000 panel members who had participated in previous surveys about Social Security knowledge. The survey was put into the field on June 26, 2018, and data collection ended on August 22, 2018. The survey had 1,652 respondents, of which 1,406 were determined to be eligible. To be eligible, panel members had to be married or partnered and neither could be currently receiving Social Security benefits. We oversampled households where both members participated in the UAS. Table 1 provides summary demographic characteristics of our eligible sample. Because our sample focuses on those who are not yet receiving social security, our sample is younger than the overall UAS sample. All respondents in our sample are either partnered (14\%) or married (86\%). 
Table 1: Summary demographic characteristics

\begin{tabular}{|c|c|}
\hline Demographic Characteristic & Mean (SD) \\
\hline \multirow{2}{*}{ Male } & 0.49 \\
\hline & $(0.500)$ \\
\hline \multirow[b]{2}{*}{ Age } & 45.07 \\
\hline & $(10.73)$ \\
\hline \multirow{2}{*}{ Partnered } & 0.14 \\
\hline & $(0.342)$ \\
\hline \multirow{2}{*}{ Less than High School } & 0.04 \\
\hline & $(0.196)$ \\
\hline \multirow{2}{*}{ High School } & 0.18 \\
\hline & $(0.385)$ \\
\hline \multirow{2}{*}{ Some college or Assoc. Degree } & 0.33 \\
\hline & $(0.471)$ \\
\hline \multirow{2}{*}{ Bachelor degree or more } & 0.45 \\
\hline & $(0.497)$ \\
\hline \multirow{2}{*}{ White, Non-Hispanic } & 0.81 \\
\hline & $(0.395)$ \\
\hline \multirow{2}{*}{ Black, Non-Hispanic } & 0.05 \\
\hline & $(0.223)$ \\
\hline \multirow{2}{*}{ Hispanic } & 0.08 \\
\hline & $(0.274)$ \\
\hline \multirow{2}{*}{ Other Race } & 0.06 \\
\hline & $(0.234)$ \\
\hline \multirow{2}{*}{ Currently Working } & 0.83 \\
\hline & $(0.373)$ \\
\hline \multirow{2}{*}{ Household income $<50 \mathrm{~K}$} & 0.25 \\
\hline & $(0.434)$ \\
\hline \multirow{2}{*}{ Household income 50-75K } & 0.20 \\
\hline & $(0.400)$ \\
\hline \multirow{2}{*}{ Household income $75-100 \mathrm{~K}$} & 0.17 \\
\hline & $(0.372)$ \\
\hline \multirow{2}{*}{ Household income 100-150K } & 0.23 \\
\hline & $(0.423)$ \\
\hline \multirow{2}{*}{ Household income $>150 \mathrm{~K}$} & 0.15 \\
\hline & $(0.358)$ \\
\hline $\mathbf{N}$ & 1406 \\
\hline
\end{tabular}

Source: UAS Wave 139, unweighted statistics presented 
Table 2 presents individual characteristics that we hypothesize may impact knowledge of Social Security programs. First, we consider financial literacy. We use a 14-point score for financial literacy taken from the National Financial Capability Study and fielded to all panel members. In our sample, the mean score is 9.83 and 58 percent of respondents answer 10 or more questions correctly. We refer to this latter group as those with high financial literacy. Second, we considered a question asked previously in the UAS about whether individuals consider themselves to be somewhat or very knowledgeable about Social Security policy. ${ }^{4}$

Based on the discussion from focus groups, we also consider that primary or equal earners might have less knowledge of spousal benefits because they themselves will not be direct beneficiaries of spousal benefits. In our sample, 56 percent report to earn more or about the same as their spouse, with the remainder reporting to earn less or that they do not know. We also hypothesize that individuals who have high confidence in the Social Security retirement system might have greater incentives to understand the programs features; those who feel Social Security rules were likely to change soon may have less incentive to learn about Social Security policy. In our sample, 38 percent reported that they were very or somewhat confident that Social Security will be able to pay the benefits at the same level entitled under current law.

\footnotetext{
${ }^{4}$ This question was measured twice in the UAS (UAS survey 16 and UAS survey 94). We use the most recent response for each respondent.
} 
Table 2: Summary Statistics for Individual Characteristics

\begin{tabular}{|l|c|}
\hline & Mean (SD) \\
\hline \multirow{2}{*}{ Financial Literacy (0-14 scale) } & 9.83 \\
\cline { 2 - 2 } Share with high financial literacy & $(3.046)$ \\
\hline \multirow{2}{*}{ Self-assessed knowledge of Social Security } & 0.58 \\
\hline \multirow{2}{*}{ Primary or equal earner } & $0.494)$ \\
\hline High confidence that social security will be & 0.60 \\
\hline able to pay benefits & $0.490)$ \\
\hline N & 0.56 \\
\hline
\end{tabular}

\section{Results}

Figure 1 presents summary statistics for general awareness of spousal and survivors benefits.

We find that more respondents have heard of survivors benefits than have heard of spousal benefits: 46 percent of respondents have heard of spousal benefits, whereas 55 percent have heard of survivors benefits. This is consistent with our findings from the focus groups. 
Figure 1: Awareness and basic knowledge of spousal and survivors benefits

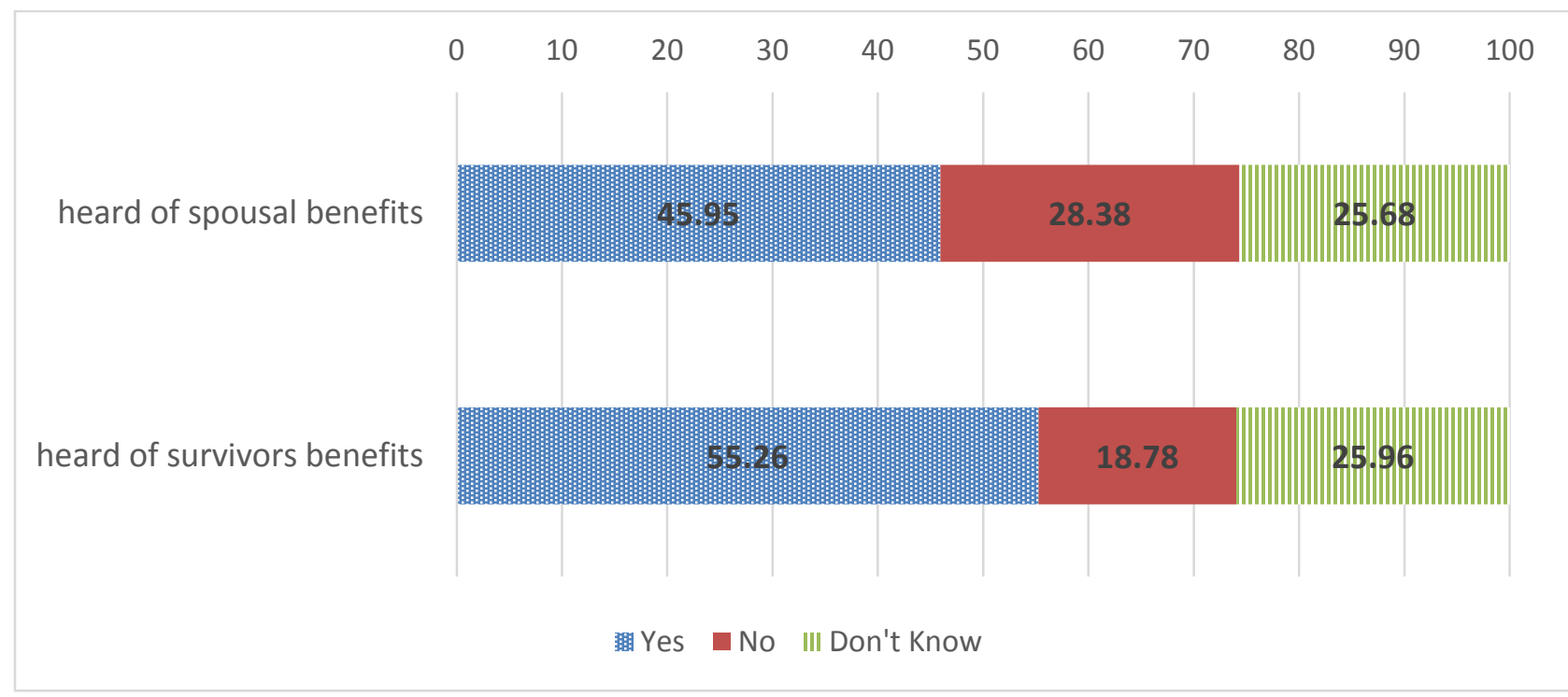

Knowledge of spousal benefits

We next turn to the five questions on spousal benefits knowledge. Each of these questions asked respondents about their knowledge of detailed facts about spousal benefits. In each of the following figures, we have reordered the answers so that the correct answer is shown in the blue pie piece in the upper right quadrant.

The first knowledge question asked about eligibility based on years of a relationship and whether benefits are available to unmarried partners. As seen in Figure 2, 27 percent of respondents choose the correct response option that spousal benefits are available to couples married for one year or longer. A further 24 percent choose the response option that spouses must be married for 10 years in order to be eligible for spousal benefits. While their answer about the length of marriage was wrong, these individuals did know that couples must be married (as opposed to partnered) to receive spousal benefits. More than 5 percent of respondents choose one of the response categories that indicates a spouse or a partner may be eligible for spousal benefits. Notably, 38 percent of respondents choose the Don't Know option. Those who are 
unaware of benefits or who expect benefits for partners could make suboptimal retirement planning decisions.

Figure 2: Eligibility for spousal benefits among married individuals

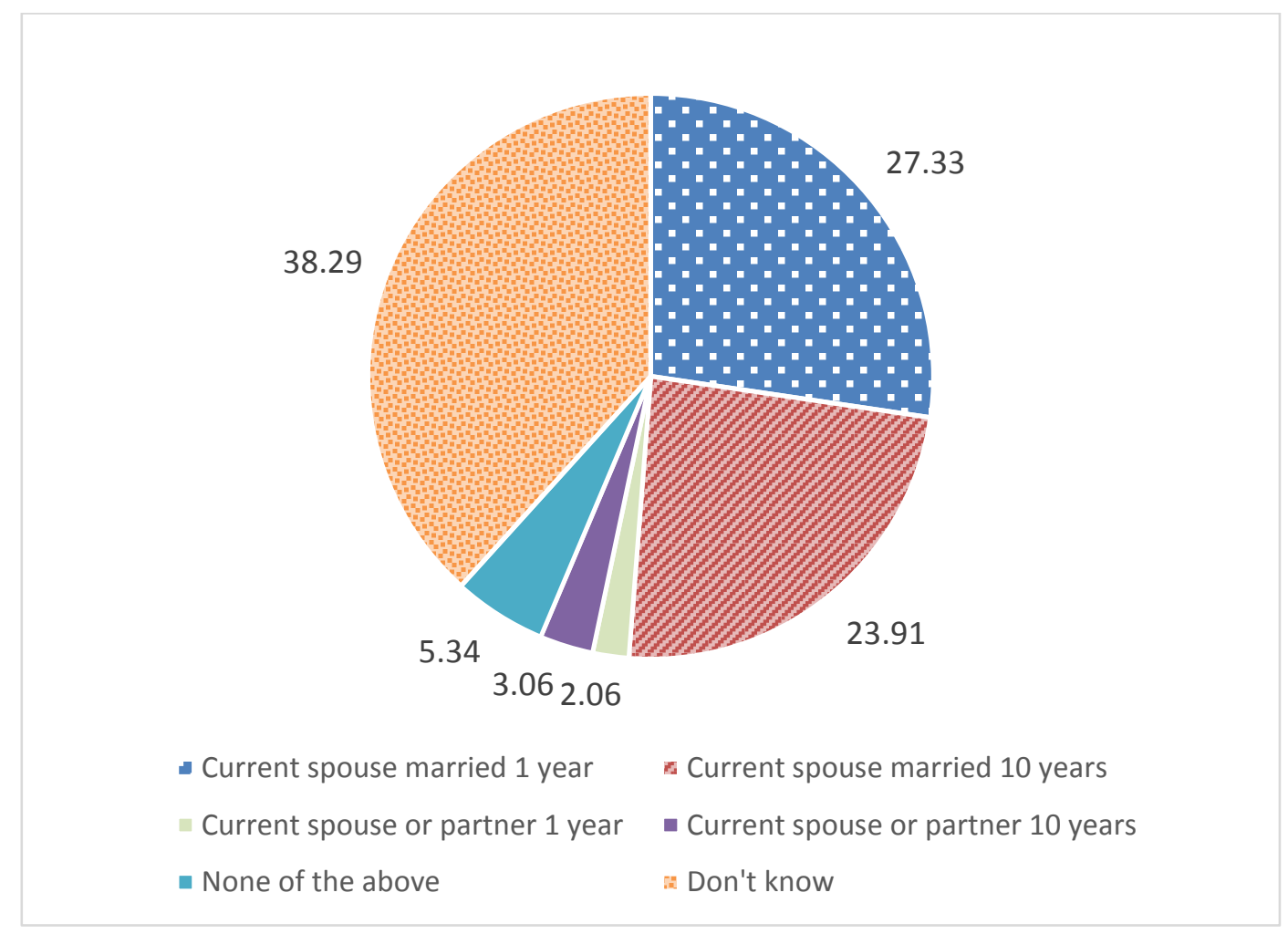

Figure 3 presents responses to the question about eligibility for spousal benefits for divorced individuals. Approximately 27 percent of respondents responded that divorced individuals who were married for at least 10 years may be eligible for spousal benefits. It is notable that 19.5 percent responded that former spouses are never eligible. About 39 percent of respondents choose the Don't Know response option. Individuals who are unaware of the correct eligibility could be less likely to provide Social Security with information necessary to obtain spousal benefits if divorced. 
Figure 3: Eligibility for Spousal Benefits among Divorced Individuals

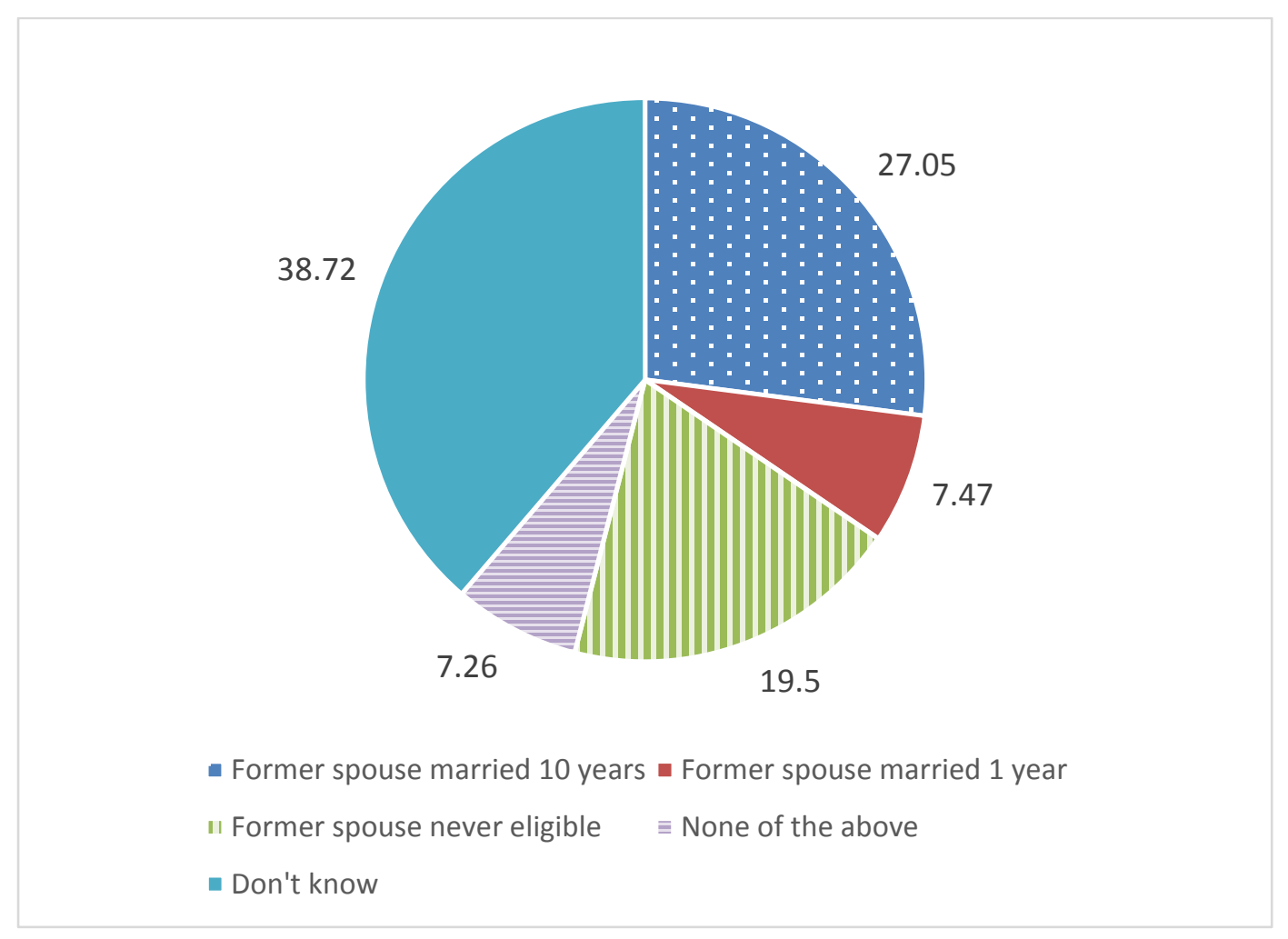

Our spousal benefits module also asked respondents about how claiming spousal benefits would affect the level of benefits for the primary earner. As seen in Figure 4, 38 percent of respondents choose the correct response option that claiming spousal benefits will have no effect on the level of the primary beneficiary's benefits. More than 22 percent choose the response category that claiming spousal benefits will lower the benefit amount for the primary beneficiary. Almost 4 percent believed the benefits of the primary beneficiary would increase; these individuals may perceive the spousal benefit as an additional benefit to beneficiaries who are married, rather than a benefit available to the spouse. The remaining 36 percent choose the Don't Know response option. 
Figure 4: Impact of spousal benefits on primary beneficiary's benefit amount

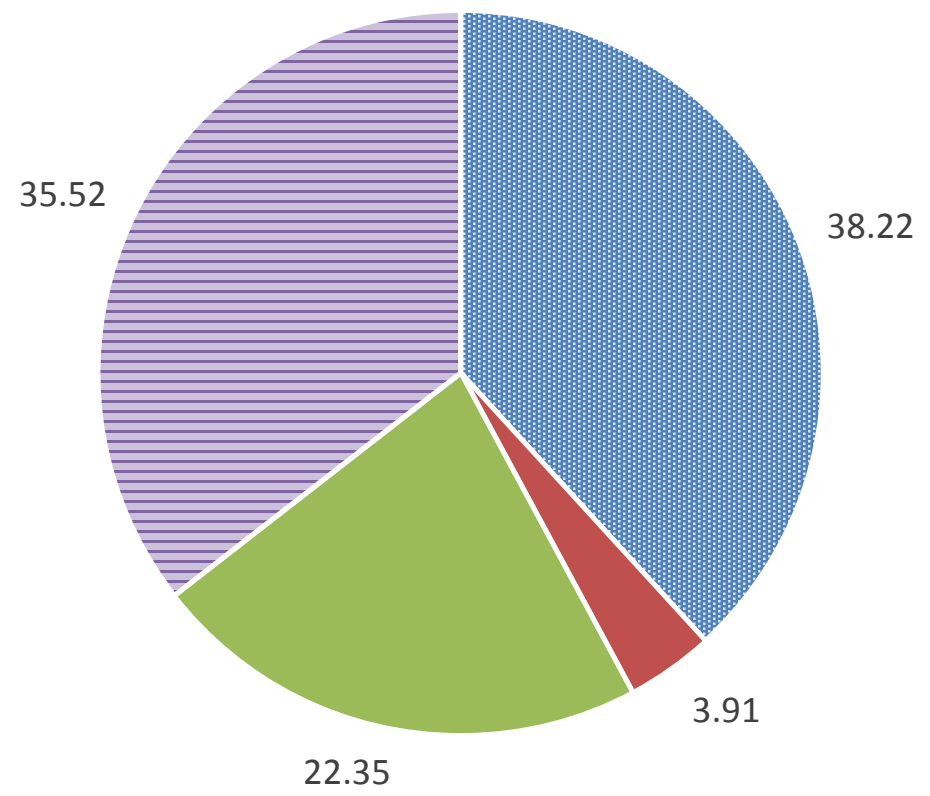

$\approx$ Stay the same $\quad$ Increase $\square$ Decrease $=$ Dont know

Figure 5 presents answers to a question about whether spousal benefits can be claimed before or after the primary beneficiary claims. Responses to this question could be influenced by knowledge of the former policy which allowed primary beneficiaries to file and then suspend their benefits so that the spouse could begin collecting benefits. More than 38 percent of respondents correctly responded that the spouse cannot claim benefits before the primary beneficiary, while 22 percent responded that the spouse can claim benefits before the primary beneficiary claims. The remainder report that they do not know. 
Figure 5: Current spouses can claim spousal retirement benefits before the primary beneficiary claims his/her own benefits.

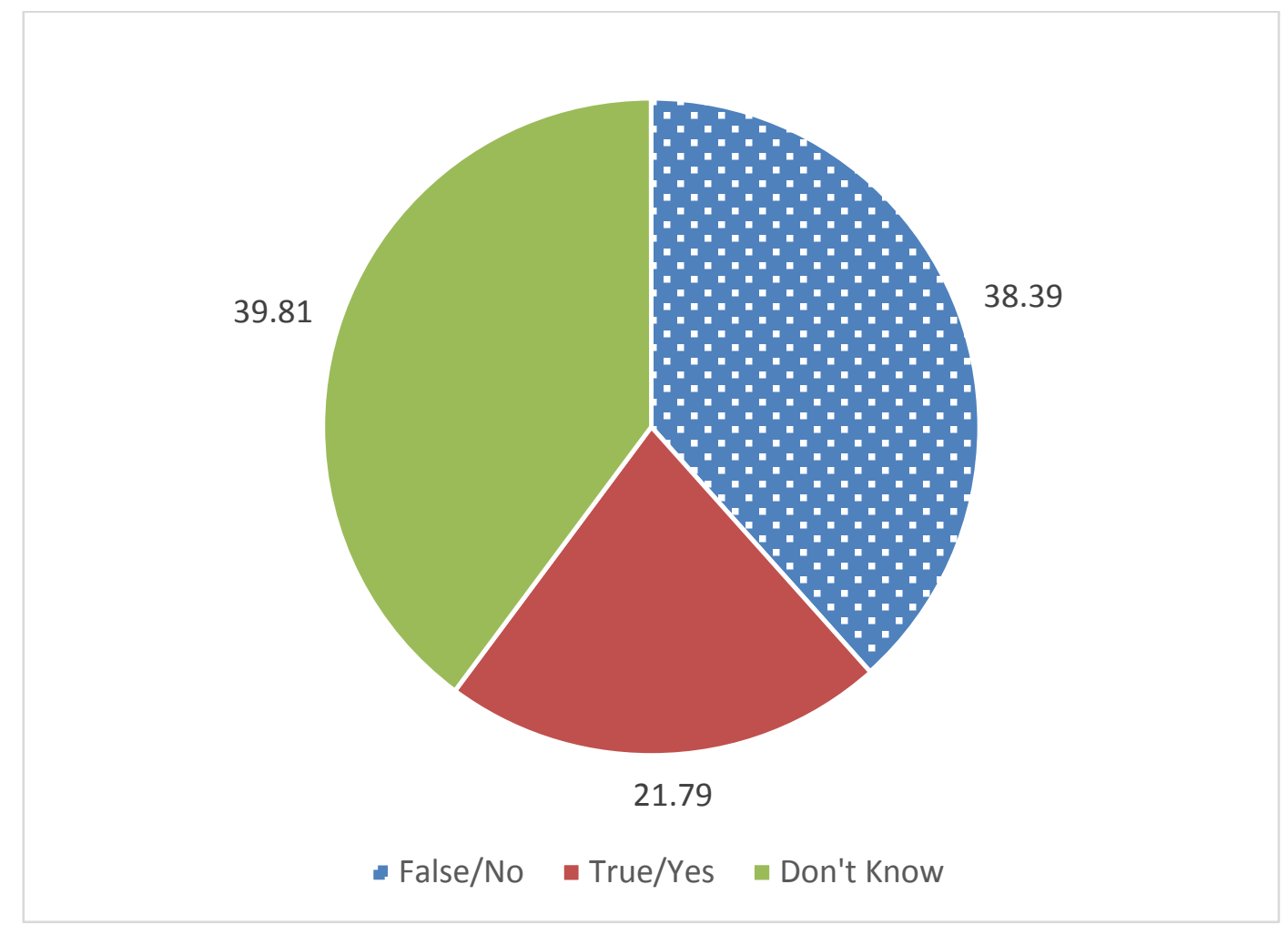

During our focus groups, after reading the Social Security webpage about spousal benefits, some participants wondered aloud if it is possible to claim the full amount of one's own benefits as well as the full amount of the spousal benefits. Figure 6 presents results from a question designed to assess whether survey respondents also exhibit this confusion. For this question it is notable that the majority of respondents report that they don't know the answer. More than onethird -34 percent - choose the correct response option that the amount of the benefit is the maximum of the spouse's own benefit or the maximum of the spousal benefit, while only 8 percent reported that they believe the maximum benefit is the spousal benefit plus their own benefit. 


\section{Figure 6: Maximum spousal benefit amounts}

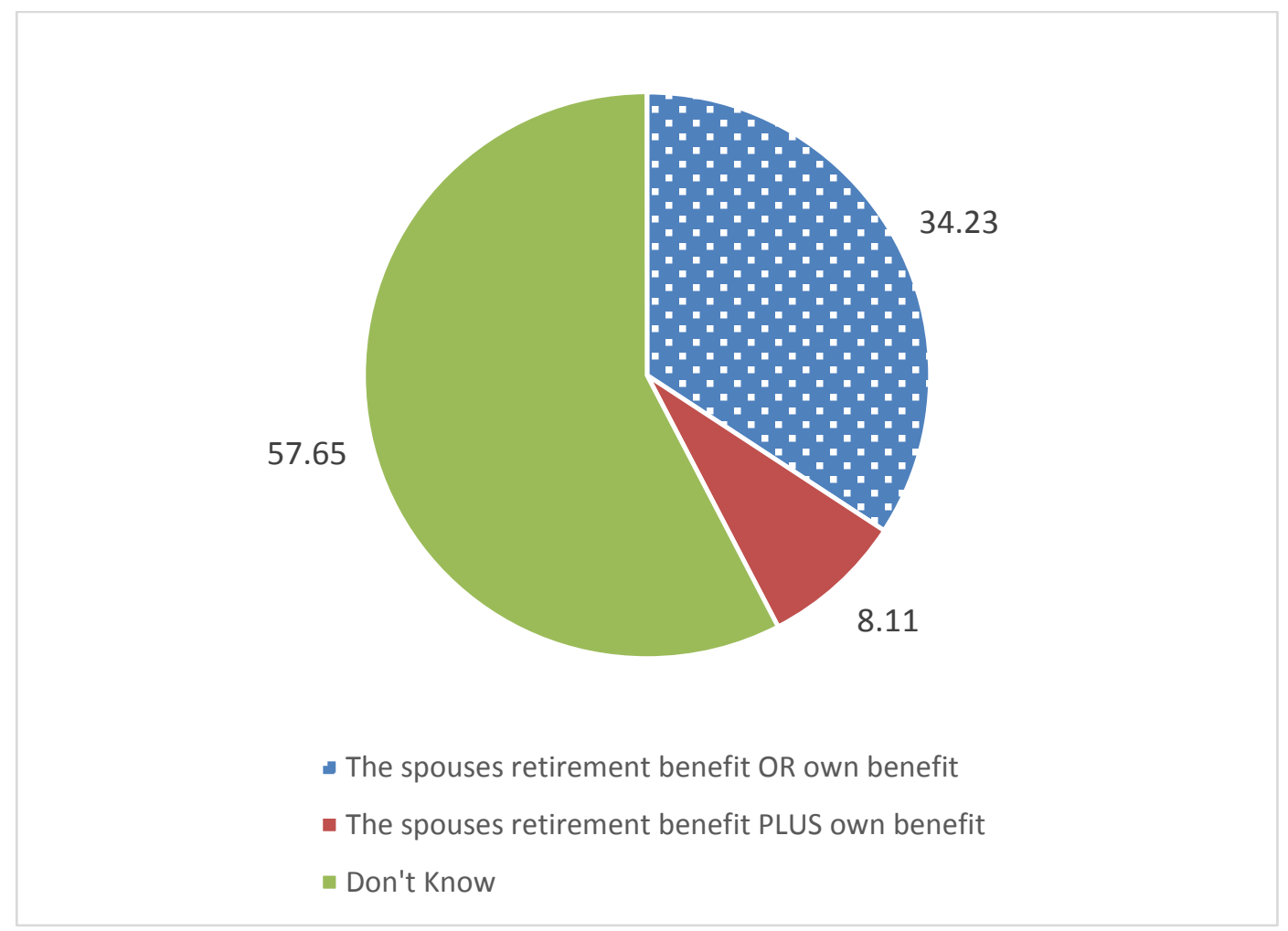

Considering Figures 2 to 6 , we see that while those reporting the correct responses typically represent the largest or second largest group of respondents, the majority of individuals do not select the correct response. Furthermore, a large fraction report that they simply don't know the correct response. Based on these five questions, presented in Figures 2 to 6, we can calculate a total number of correct answers. On average, respondents answer only 1.65 of the five questions correctly. This represents a relatively low level of knowledge about spousal benefits.

Individuals who are misinformed or uninformed about spousal benefits may not optimally plan for retirement, or may fail to apply for benefits for which they are eligible.

One possible explanation for the low average level of knowledge about spousal benefits is that this result is driven by those with low financial literacy, low familiarity with the Social Security retirement program, in general, or low confidence in the Social Security system. 
Another possible explanation is that primary earners have low knowledge about spousal benefits, because these are not benefits that they would expect to receive. Table 3 presents summary statistics on awareness and knowledge of spousal benefits by financial literacy, self-assessed Social Security knowledge, confidence in the Social Security system, and primary earner status. In the lower panel of Table 3, we present results on respondents' subjective knowledge about spousal benefits. We use respondents' subjective probability distributions over the number of correct responses they think they provided to calculate their expected number of questions correct as well as the gap between the expected number and the actual number of correct responses. We also report the results of t-tests comparing each variable for those with low or high financial literacy, for those with low or high subjective knowledge of Social Security, for those with low or high confidence in Social Security, and for primary or secondary earners.

Those with higher financial literacy and subjective knowledge about Social Security in general are more likely to have heard of spousal benefits. In particular, 53 percent of those with high financial literacy have heard of spousal benefits, while only 36 percent of those with low financial literacy have. For subjective knowledge, the results are nearly identical: The difference is 54 percent versus 33 percent. Those who have high confidence in Social Security are also more likely to have heard about spousal benefits than those who have low confidence in Social Security (52 percent versus 42 percent). Interestingly, primary earners are more likely to report having heard of spousal benefits than secondary earners, even though primary earners are unlikely to be eligible for spousal benefits: 49 percent of primary earners have heard of spousal benefits and 43 percent of secondary earners have heard of spousal benefits. It is possible that primary earners are more likely to be the financial decision maker, and generally have more knowledge about Social Security. 
In terms of the total number of correct responses, we find that high financial literacy, high subjective knowledge of Social Security, and being a primary earner are associated with answering a greater number of questions correctly. Those with high financial literacy answered, on average, 1.82 questions out of five about spousal benefits correctly, while those with low financial literacy only answered 1.43 correctly. The gap is slightly lower for subjective knowledge of Social Security (1.76 versus 1.49$)$. However, it is notable that even among those with high financial literacy or those who describe themselves as knowledgeable about Social Security, the average number of correct responses is less than two. Primary earners, on average, correctly answered 1.77 questions on spousal benefits out of five, whereas, secondary earners, on average, correctly answered 1.51 questions. Those with high confidence in Social Security answered more questions correctly, on average, than those with low confidence, but this difference is not statistically significant. 
Table 3: Across group comparisons of spousal benefits knowledge

\begin{tabular}{|c|c|c|c|c|c|c|c|c|c|}
\hline & $\begin{array}{c}\text { Full } \\
\text { sample }\end{array}$ & $\begin{array}{l}\text { High Fin. } \\
\text { Lit }\end{array}$ & $\begin{array}{l}\text { Low Fin. } \\
\text { Lit }\end{array}$ & $\begin{array}{l}\text { High Subj. } \\
\text { Soc Sec } \\
\text { Knowledge }\end{array}$ & $\begin{array}{l}\text { Low Subj. } \\
\text { Soc Sec } \\
\text { Knoweldge }\end{array}$ & $\begin{array}{c}\text { High } \\
\text { Confidence } \\
\text { in Soc Sec }\end{array}$ & $\begin{array}{c}\text { Low } \\
\text { Confidence } \\
\text { in Soc Sec }\end{array}$ & $\begin{array}{l}\text { Primary } \\
\text { Earner }\end{array}$ & $\begin{array}{l}\text { Secondary } \\
\text { Earner }\end{array}$ \\
\hline $\begin{array}{l}\text { Heard of Social Security } \\
\text { spousal benefits }\end{array}$ & $\begin{array}{c}0.46 \\
(0.499)\end{array}$ & $\begin{array}{l}0.53^{* * *} \\
(0.499)\end{array}$ & $\begin{array}{c}0.36 \\
(0.479)\end{array}$ & $\begin{array}{l}0.54^{* * *} \\
(0.498)\end{array}$ & $\begin{array}{c}0.33 \\
(0.470)\end{array}$ & $\begin{array}{l}0.52^{* * *} \\
(0.500)\end{array}$ & $\begin{array}{c}0.42 \\
(0.494)\end{array}$ & $\begin{array}{c}0.49 * \\
(0.500)\end{array}$ & $\begin{array}{c}0.43 \\
(0.495)\end{array}$ \\
\hline $\begin{array}{l}\text { Number of correct spousal } \\
\text { benefit questions (out of } 5 \text { ) }\end{array}$ & $\begin{array}{c}1.65 \\
(1.305)\end{array}$ & $\begin{array}{l}1.82^{* * *} \\
(1.327)\end{array}$ & $\begin{array}{c}1.43 \\
(1.240)\end{array}$ & $\begin{array}{l}1.76^{* * *} \\
(1.325)\end{array}$ & $\begin{array}{c}1.49 \\
(1.258)\end{array}$ & $\begin{array}{c}1.71 \\
(1.330)\end{array}$ & $\begin{array}{c}1.62 \\
(1.288)\end{array}$ & $\begin{array}{l}1.77^{* * *} \\
(1.330)\end{array}$ & $\begin{array}{c}1.51 \\
(1.258)\end{array}$ \\
\hline $\begin{array}{l}\text { Actual number of correct } \\
\text { spousal benefit questions } \\
\text { (out of 5) Conditional on }\end{array}$ & $\begin{array}{c}1.97 \\
(1.251)\end{array}$ & $\begin{array}{l}2.06^{* *} \\
(1.275)\end{array}$ & $\begin{array}{c}1.80 \\
(1.191)\end{array}$ & $\begin{array}{l}2.04 * \\
(1.270)\end{array}$ & $\begin{array}{c}1.84 \\
(1.211)\end{array}$ & $\begin{array}{c}1.98 \\
(1.290)\end{array}$ & $\begin{array}{c}1.95 \\
(1.226)\end{array}$ & $\begin{array}{c}1.99 \\
(1.290)\end{array}$ & $\begin{array}{c}1.93 \\
(1.189)\end{array}$ \\
\hline $\begin{array}{l}\text { Expected number of correct } \\
\text { spousal benefit questions } \\
\text { (out of 5) }\end{array}$ & $\begin{array}{c}2.22 \\
(1.338)\end{array}$ & $\begin{array}{c}2.26 \\
(1.303)\end{array}$ & $\begin{array}{c}2.14 \\
(1.396)\end{array}$ & $\begin{array}{l}2.41 * * * \\
(1.324)\end{array}$ & $\begin{array}{c}1.91 \\
(1.304)\end{array}$ & $\begin{array}{l}2.46 * * * \\
(1.332)\end{array}$ & $\begin{array}{c}2.06 \\
(1.318)\end{array}$ & $\begin{array}{l}2.31^{* *} \\
(1.321)\end{array}$ & $\begin{array}{c}2.07 \\
(1.353)\end{array}$ \\
\hline $\begin{array}{l}\text { Expected minus Actual } \\
\text { number correct }\end{array}$ & $\begin{array}{c}0.25 \\
(1.380)\end{array}$ & $\begin{array}{c}0.20 \\
(1.316)\end{array}$ & $\begin{array}{c}0.34 \\
(1.485)\end{array}$ & $\begin{array}{l}0.37^{* * *} \\
(1.381)\end{array}$ & $\begin{array}{c}0.07 \\
(1.362)\end{array}$ & $\begin{array}{c}0.47^{* * *} \\
(1.413)\end{array}$ & $\begin{array}{c}0.11 \\
(1.338)\end{array}$ & $\begin{array}{c}0.32 * \\
(1.401)\end{array}$ & $\begin{array}{c}0.14 \\
(1.339)\end{array}$ \\
\hline $\mathbf{N}$ & 1406 & 814 & 592 & 838 & 562 & 541 & 865 & 789 & 616 \\
\hline
\end{tabular}


Turning to respondents' self-assessments of their knowledge of spousal benefits, we note that 30.16 percent of respondents responded "don't know" to the subjective probability distributions over the number of correct responses. Furthermore, those who do respond to these subjective probability quesitons have a much higher actual number of questions correct than those who do not (1.97 versus 1.65$)$. We see that respondents overestimate their knowledge of spousal benefits: The average expected number of correct responses is 2.22 , but the average actual number of correct responses is 1.97 on average, and the average difference between expected and actual number of correct responses is 0.25 .

When we make comparisons of spousal benefit knowledge by financial literacy, we find that even though the actual number correct is higher for those with high financial literacy compared to those with low financial literacy, the expected number correct is not statistically significantly different across these two groups. This suggests that those with high financial literacy are less likely to overestimate their spousal benefits knowledge, compared to those with low financial literacy. Those with high subjective knowledge of Social Security and those with high confidence in Social Security answer more questions correctly than those with low subjective knowledge of Social Security or those with low confidence in Social Security, respectively, but also perceive that they answer more questions correctly, leading to higher overestimation. Likewise, those primary earners answer more questions correctly than secondary earners, and also expect that they answer more questions correctly, and therefore, are more likely to overestimate the number of correct question.

\section{Knowledge of survivors benefits}

We next turn to questions about survivors benefits. The first four of these questions were asked as true/false questions, thus all response options are the same and we present the results 
together in Figure 7. We show the correct answer in parentheses. The fifth question was a multiple choice question and is presented in Figure 8.

The first question asked about the length of marriage necessary to receive benefits. The largest group (43 percent) correctly respond that those married at least nine months are eligible for survivors benefits, while 40 percent report don't know. Turning to the second question, 46 percent incorrectly respond that an individual who remarries is no longer eligible for survivors benefits. The statement (emphasis added) says, "If the deceased's widow/widower ever remarries, then the widow/widower is no longer eligible for survivors benefits," when in fact if a widow or widower remarries after age 60 , he/she may still be eligible for survivors benefits. Almost one-quarter of respondents do answer this question correctly, however we did not explicitly ask about the age 60 remarriage rule for the sake of simplicity. Thus it is possible that those who correctly answer the question, incorrectly believe that those who remarry at a younger age are eligible for survivors benefits. Turning to the third question, 36 percent incorrectly respond that unmarried partners may be eligible for survivors benefits, while 23 percent correctly answer this question. The fourth question asks about survivors benefits for divorced spouses. More than 38 percent correctly identify that divorced individuals married for 10 years or more may be eligible for spousal benefits. It is notable that in all four questions, we again see a significant proportion (between 31 and 43 percent) responding “Don’t know." 
Figure 7: Survivors benefits knowledge questions

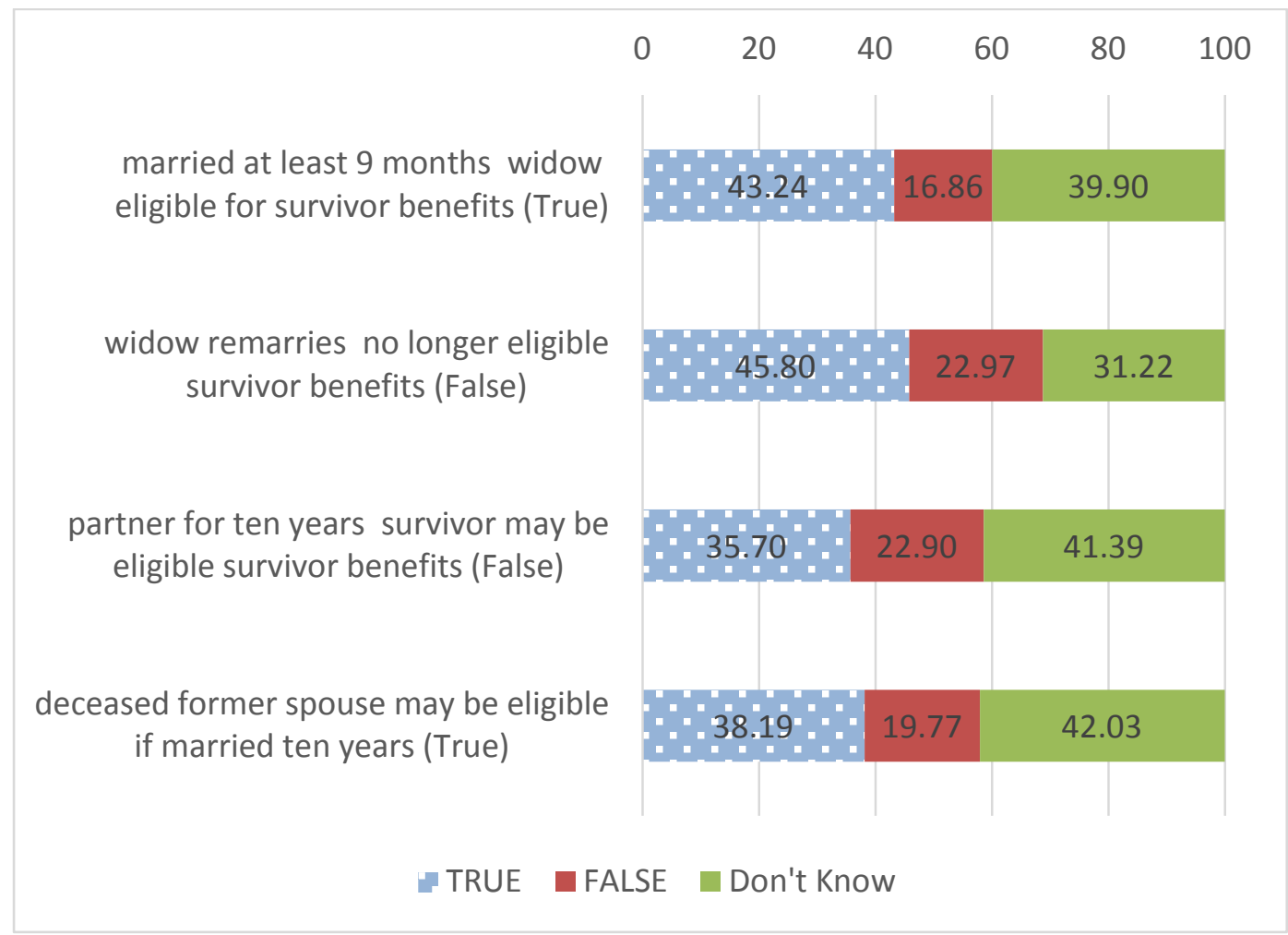

Figure 8 presents the results of the fifth survivors benefit knowledge question, which mirrors the question about maximum spousal benefits above, asking if survivors benefits are in addition to the survivor's own benefit or top up the survivor's own benefits. Similar to above, 33 percent perceive the benefits to be a top up, while more than half report that they don't know. 
Figure 8: Maximum survivor benefit amounts

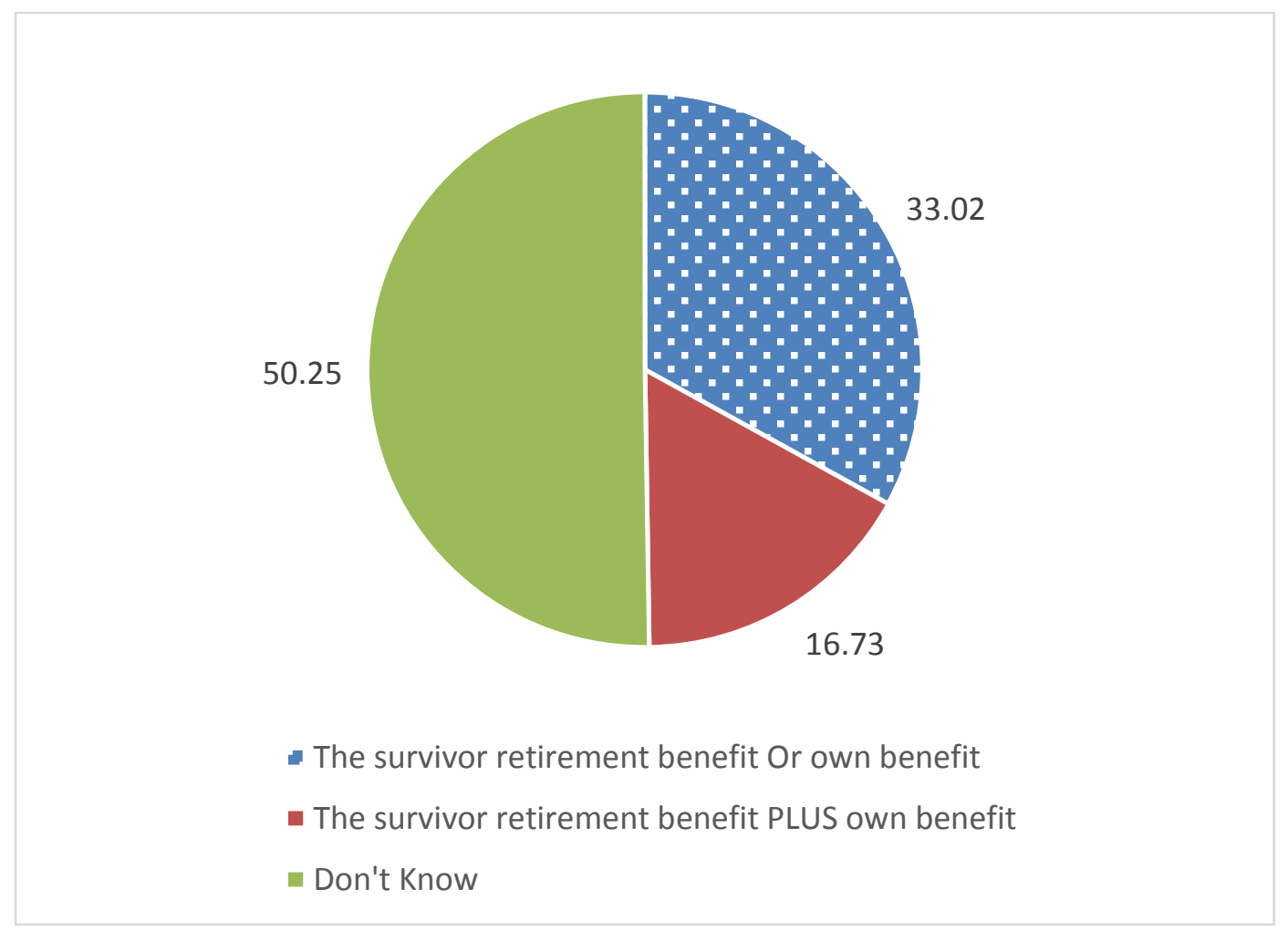

Considering Figures 7 and 8, we see that while many report the correct responses, the majority of individuals do not select the correct response. Furthermore, a large fraction report that they simply don't know the correct response. For the two questions that are false, the percent correctly reporting false is lower than the percent incorrectly reporting true. This is possibly in part based on a bias toward selecting a true response in multiple choice questions. Based on these five questions, presented in Figures 7 and 8, we can calculate a total number of correct. On average, respondents answer only 1.60 of the five questions correctly, which is lower but not statistically significantly different from the number of correct responses to the spousal benefits questions. As with spousal benefits, this represents a relatively low level of knowledge about survivors benefits. Individuals who are misinformed or uninformed about survivors benefits may not optimally plan for retirement, or may fail to apply for benefits for which they are eligible. 
As we did with spousal benefits, we consider whether knowledge of survivors benefits is different among those with high financial literacy, those who previously reported greater knowledge about Social Security in general, those with higher confidence in Social Security, or primary earners. Table 4 presents summary statistics on awareness, measured knowledge of survivors benefits, and self-assessed knowledge of survivors benefits by financial literacy, selfassessed Social Security knowledge, confidence in Social Security, and primary earner status. We also report the results of t-tests comparing each variable for those with low or high financial literacy, for those with low or high subjective knowledge of Social Security, for those with low or high confidence in Social Security, and for primary versus secondary earners.

Those with higher financial literacy, higher subjective knowledge about Social Security in general, and those with higher confidence in Social Security, and primary earners are more likely to have heard of survivors benefits. This gap in awareness between high financial literacy respondents and low financial literacy respondents is even larger than for spousal benefits. Sixtyseven percent of those with high financial literacy are aware of survivors benefits, while only 40 percent of those with low financial literacy are. Among those with high subjective knowledge of Social Security, 64 percent have heard of survivors benefits, while among those with low subjective knowledge only 42 percent have. Those with high confidence in Social Security are marginally more likely than those with low confidence in Social Security to have heard of survivors benefits: 59 percent versus 53 percent. Again, primary earners are more likely to have heard of survivors benefits than secondary earners (61 percent versus 48 percent).

In terms of the total number of correct responses, we find that high financial literacy, high subjective knowledge of Social Security, and being a primary earner are associated with answering a greater number of questions correctly. Those with high financial literacy answered, 
on average, 1.78 questions out of five about survivors benefits correctly, while those with low financial literacy only answered 1.36 correctly. The gap is slightly lower for those with high subjective knowledge of Social Security compared to those with low subjective knowledge of Social Security (1.72 versus 1.44$)$ as well as for primary versus secondary earners (1.70 versus 1.49). As with spousal benefits, it is notable that even among those with high financial literacy or those who describe themselves as knowledgeable about Social Security, the average number of correct responses is less than two. 
Table 4: Across group comparisons of survivors benefits knowledge

\begin{tabular}{|c|c|c|c|c|c|c|c|c|c|}
\hline & $\begin{array}{c}\text { Full } \\
\text { sample }\end{array}$ & $\begin{array}{l}\text { High Fin. } \\
\quad \text { Lit }\end{array}$ & $\begin{array}{l}\text { Low Fin. } \\
\text { Lit }\end{array}$ & $\begin{array}{l}\text { High Subj. } \\
\text { Soc Sec } \\
\text { Knowledge }\end{array}$ & $\begin{array}{l}\text { Low Subj. } \\
\text { Soc Sec } \\
\text { Knoweldge }\end{array}$ & $\begin{array}{l}\text { High } \\
\text { Confidence } \\
\text { in Soc Sec }\end{array}$ & $\begin{array}{l}\text { Low } \\
\text { Confidence } \\
\text { in Soc Sec }\end{array}$ & $\begin{array}{l}\text { Primary } \\
\text { Earner }\end{array}$ & $\begin{array}{c}\text { Secondary } \\
\text { Earner }\end{array}$ \\
\hline \multirow{2}{*}{$\begin{array}{l}\text { Heard of Social Security } \\
\text { survivor benefits }\end{array}$} & 0.55 & $0.67^{* * *}$ & 0.40 & $0.64 * * *$ & 0.42 & $0.59 *$ & 0.53 & $0.61 * * *$ & 0.48 \\
\hline & $(0.497)$ & $(0.472)$ & $(0.489)$ & $(0.480)$ & $(0.495)$ & $(0.492)$ & $(0.500)$ & $(0.488)$ & $(0.500)$ \\
\hline \multirow{2}{*}{$\begin{array}{l}\text { Number of correct survivor } \\
\text { benefit questions (out of } 5 \text { ) }\end{array}$} & 1.60 & $1.78 * * *$ & 1.36 & $1.72 * * *$ & 1.44 & 1.65 & 1.58 & $1.70^{* *}$ & 1.49 \\
\hline & $(1.283)$ & $(1.284)$ & $(1.242)$ & $(1.292)$ & $(1.251)$ & $(1.273)$ & $(1.289)$ & $(1.282)$ & $(1.275)$ \\
\hline \multirow{2}{*}{$\begin{array}{l}\text { Actual number of correct } \\
\text { survivor benefit questions } \\
\text { (out of } 5 \text { ) Conditional on } \\
\text { measuring expected number }\end{array}$} & 1.89 & $2.02 * * *$ & 1.65 & $1.99 * *$ & 1.72 & 1.91 & 1.87 & 1.94 & 1.80 \\
\hline & $(1.247)$ & $(1.249)$ & (1.209) & $(1.269)$ & (1.195) & $(1.242)$ & $(1.251)$ & $(1.243)$ & $(1.250)$ \\
\hline \multirow{2}{*}{$\begin{array}{l}\text { Expected number of correct } \\
\text { survivor benefit questions } \\
\text { (out of } 5 \text { ) }\end{array}$} & 2.02 & 2.05 & 1.97 & $2.19 * * *$ & 1.74 & $2.20 * * *$ & 1.89 & 2.08 & 1.92 \\
\hline & (1.299) & $(1.232)$ & (1.410) & (1.292) & $(1.264)$ & (1.348) & (1.249) & (1.299) & (1.295) \\
\hline \multirow{2}{*}{$\begin{array}{l}\text { Expected minus Actual } \\
\text { number correct }\end{array}$} & 0.13 & $0.03^{* *}$ & 0.32 & 0.20 & 0.03 & $0.29 * *$ & 0.02 & 0.14 & 0.11 \\
\hline & $(1.475)$ & $(1.393)$ & $(1.592)$ & $(1.477)$ & $(1.470)$ & $(1.455)$ & $(1.480)$ & $(1.453)$ & $(1.508)$ \\
\hline $\mathbf{N}$ & 1406 & 814 & 592 & 838 & 562 & 541 & 865 & 789 & 616 \\
\hline
\end{tabular}


Turning to respondents' self-assessments of their knowledge on survivors benefits, we again note that 35.35 percent of respondents responded "don't know" to the subjective probability distributions over the number of correct responses. Furthermore, those who do respond have a much higher actual number of questions correct than those who do not (1.89 versus 1.60$)$. For survivors benefits, respondents expected that they answered 2.02 questions correctly, but on average only 1.89 questions were actually correct, and the average difference between expected and actual number of correct responses is 0.13 . As with spousal benefits, we see that respondents overestimate their knowledge of survivors benefits, although this overestimation is smaller.

When we make comparisons of survivors benefit knowledge by financial literacy, we find that the expected number correct is not statistically significantly different across high and low financial literacy groups. Those with low financial literacy are more likely to overestimate their knowledge of survivors benefits. Those with high subjective knowledge of Social Security answer more questions correctly than those with low subjective knowledge of Social Security, but also perceive that they answer more survivors benefits questions correctly, leading to marginally higher overestimation. Those with high confidence Social Security answer approximately the same number of questions correctly as those with low confidence in Social Security, but perceive that they answer more survivors benefits questions correctly, leading to higher overestimation.

\section{Comparison of knowledge within couples}

Our results for the whole sample suggest that overall knowledge is low. One possibility is that within couples, individuals specialize with one learning about Social Security benefits and the other relying on the more knowledgeable spouse, perhaps with only the spouse who will receive spousal benefits taking the time to learn about spousal benefits. To test this hypothesis, 
our data include an oversample of household where both spouses or partners participate in the UAS. In total, both members of 188 couples participated in our survey. We created a merged sample that allows us to compare the responses of both members of a couple. The sample size for this analysis is small, but allows us to consider whether there is suggestive evidence of specialization within couples.

We distinguish between the primary earner and the secondary earner, using each spouse's report of whether his or her lifetime earnings are higher than the other spouse. If each spouse's answer confirms the other spouse's answer, then consider the agreed upon higher earning spouse to the be the primary earner. If their responses contradict each other, then we assign the older spouse to be the primary earner. In our sample of couples, 68 percent of primary earners are men. ${ }^{5}$

We calculated the difference in the number of correct responses from each spouse for each block of five questions about spousal or survivor benefits, equivalent to the total number correct for the primary earner minus the total number correct for the secondary earner. Panel A of Figure 9 shows the distribution of the difference in responses for spousal benefits. Panel B shows the distribution of the difference in responses of survivor benefits. The distributions are relatively symmetric, although the distribution for spousal benefits is slightly skewed to the right, with the primary earner answering slightly more questions correctly. These results do not suggest that couples specialize in knowledge; most couples answer the same number of questions correctly or are only different by one. This may be a result of the relatively low knowledge of both types of benefits.

\footnotetext{
${ }^{5}$ Only four couples are same-sex couples.
} 
Figure 9: Distribution in difference of number of correct answers

Panel A: Spousal Benefits

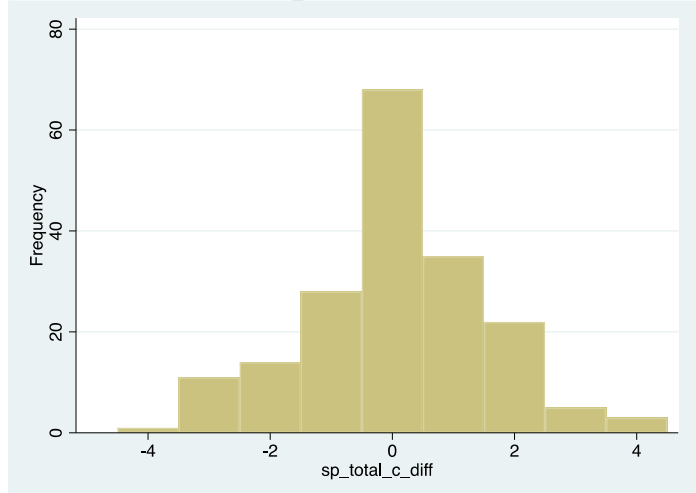

Panel B: Survivor Benefits

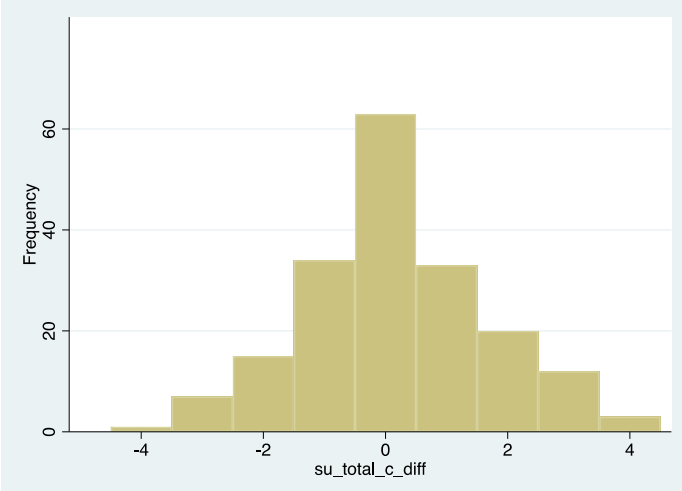

Next, we consider the correlation between knowledge of spousal and survivors benefits for both spouses. Table 5 presents the simple correlations. In contrast to our hypothesis, the correlations across spouses are positive; if spouses were specializing, we would expect the correlation to be negative. Overall, the across spouse correlations are relatively low, but the within spouse across subject correlations are higher. The correlation between the two spouses' knowledge of spousal benefits is 0.294 and the correlation between the two spouses' knowledge of survivors benefits is 0.297 . In contrast, the correlation between the primary earner's knowledge of spousal benefits and knowledge of survivors benefits is 0.461 , and the correlation for secondary earners is 0.375 . 
Table 5: Correlation between primary and secondary earner's knowledge

\begin{tabular}{|c|c|c|c|c|}
\hline & $\begin{array}{c}\text { Primary } \\
\text { earner's } \\
\text { knowledge } \\
\text { spousal benefits }\end{array}$ & $\begin{array}{c}\text { Secondary } \\
\text { earner's } \\
\text { knowledge } \\
\text { spousal benefits }\end{array}$ & $\begin{array}{c}\text { Primary } \\
\text { earner's } \\
\text { knowledge } \\
\text { survivors } \\
\text { benefits }\end{array}$ & $\begin{array}{c}\text { Secondary } \\
\text { earner's } \\
\text { knowledge } \\
\text { survivors } \\
\text { benefits }\end{array}$ \\
\hline $\begin{array}{l}\text { Primary } \\
\text { earner's } \\
\text { knowledge } \\
\text { spousal benefits }\end{array}$ & 1.0000 & & & \\
\hline $\begin{array}{l}\text { Secondary } \\
\text { earner's } \\
\text { knowledge } \\
\text { spousal benefits }\end{array}$ & 0.2940 & 1.0000 & & \\
\hline $\begin{array}{l}\text { Primary } \\
\text { earner's } \\
\text { knowledge } \\
\text { survivors } \\
\text { benefits }\end{array}$ & 0.4611 & 0.2302 & 1.0000 & \\
\hline $\begin{array}{l}\text { Secondary } \\
\text { earner's } \\
\text { knowledge } \\
\text { survivors } \\
\text { benefits }\end{array}$ & 0.2248 & 0.3747 & 0.2973 & 1.0000 \\
\hline
\end{tabular}

We also considered the correlation between spouses for each question, reported in Table 6 below. The correlation was highest for questions where in the majority of couples both spouses gave an incorrect answer. 
Table 6: Correlation in spouse's responses by question

\begin{tabular}{|l|c|}
\hline & Correlation \\
\hline Spousal Benefits & \\
\hline Q1. Eligibility if married & 0.2194 \\
\hline Q2. Eligibility if divorced & 0.2524 \\
\hline Q3. Impact on primary beneficiary's benefits & 0.1722 \\
\hline Q4. Claim spousal benefits first & 0.1140 \\
\hline Q5. Benefits in addition or instead & 0.1305 \\
\hline & \\
\hline Survivors benefits & 0.1708 \\
\hline Q1. Marriage length and eligibility & 0.0802 \\
\hline Q2. Remarriage & 0.1580 \\
\hline Q3. Partner eligibility & 0.2501 \\
\hline Q4. Eligibility if divorced & 0.0275 \\
\hline Q5. Benefits in addition or instead
\end{tabular}

These results suggest that couples do not specialize, with one spouse taking greater responsibility for understanding spousal benefits.

\section{Conclusions}

Overall, our results suggest that knowledge of spousal and survivors benefits is low. Individuals who are misinformed or uninformed about benefits may not optimally plan for retirement, or may fail to apply for benefits for which they are eligible. Furthermore, our results suggest that people's perceptions of their knowledge is misaligned with their actual knowledge, with many perceiving that they know more about Social Security than they actually do.

The primary limitation of our research is expected values of the number of questions answered correctly are low, suggesting that our questions were difficult. It is possible that results would have been more promising if questions were easier. However, the details of spousal and survivors benefits are complicated, and simpler questions may have been too general to be meaningful.

The rules governing spousal and survivors benefits are complex. Current knowledge of these 
rules is low. The results in this paper suggest particular areas where policymakers might be able to increase knowledge of spousal and survivors benefits. However, future research is needed to better understand how to increase knowledge in this area. 


\section{References}

Anderson, A, Baker, F., and Robinson, D.T. (2017). Precautionary Savings, Retirement Planning and Misperceptions of Financial literacy. Journal of Financial Economics, 126(2), 383398.

Baker, Michael. 2002. "The Retirement Behavior of Married Couples: Evidence from the Spouse's Allowance." Journal of Human Resources, 37 (1):1-34. doi: http://jhr.uwpress.org/content/by/year.

Banks, James, Richard Blundell, and María Casanova Rivas. 2010. "The Dynamics of Retirement Behavior in Couples: Reduced-Form Evidence from England and the US." Mimeo, University College London and Institute for Fiscal Studies. http://www.econ.ucla.edu/casanova/Files/Main_ELSA_HRS.pdf

Carman, Katherine Grace and Angela A. Hung. 2017. "Household Retirement Saving: The Location of Savings Between Spouses.” Santa Monica, CA: RAND Corporation. https://www.rand.org/pubs/working_papers/WR1166.html .

Coile, Courtney. 2004. "Retirement Incentives and Couples' Retirement Decisions." Topics in Economic Analysis and Policy 4 (1):1-28. doi: http://www.degruyter.com/view/j/bejeap.

Gustman, Alan L., and Thomas L. Steinmeier. 2004. "Social Security, Pensions and Retirement Behaviour within the Family." Journal of Applied Econometrics, 19 (6):723-737. doi: http://onlinelibrary.wiley.com/journal/10.1002/\%28ISSN\%291099-1255/issues.

Hurd, Michael D. 1990. "The Joint Retirement Decision of Husbands and Wives." In Issues in the Economics of Aging, edited by David A. Wise, 231-254. A National Bureau of Economic Research Project Report. Chicago and London: University of Chicago Press. 
Lalive, Rafael, and Stefan Staubli. 2014. "How Does Raising Women's Full Retirement Age Affect Labor Supply, Income, and Mortality? Evidence from Switzerland." Joint Meeting of the Retirement Research Consortium Conference Volume.

Maestas, Nicole. 2001. "Labor, Love and Leisure: Complementarity and the Timing of Retirement by Working Couples." Mimeo. Berkeley: Xerox.

Michaud, P. and F. Vermeulen. 2011. "A Collective Labor Supply Model with Complementarities in Leisure: Identification and Estimation by Means of Panel Data. Labour Economics, 18(2011): 159-167.

Moore, D. A., \& Healy, P. J. (2008). The trouble with overconfidence. Psychological Review, 115(2), 502-517.

Social Security Administration. "Income of the Population 55 or Older, 2012." SSA Publication No. 13-11871 (2014). http://www.ssa.gov/policy/docs/statcomps/income_pop55/2012/incpop12.pdf. 